IRSTI 62.13 .99

\author{
${ }^{1 *}$ A. Akindykova, ${ }^{2}$ C. Cakir-Kiefer, ${ }^{1}$ A. Baubekova, ${ }^{2}$ S. Jurjanz \\ ${ }^{1}$ Al-Farabi Kazakh National University, Almaty, Kazakhstan \\ ${ }^{2}$ University of Lorraine, Vandoeuvre-lès-Nancy, France \\ *e-mail: akindykova@gmail.com
}

\title{
Isolation and characterization of camel milk proteins
}

\begin{abstract}
Camel milk is an important constituent of Kazakh diet. Populaces of several regions of the country used camels as one of the basic sources of nutrients for many centuries. Camel milk contains high amounts of the immune-active proteins - lysozyme, lactoferrin, lactoperoxidase, immunoglobulins. It is also rich in vitamin C. Like any other, camel milk is highly perishable, with losses occurring during work at farm and under industrial conditions. These losses can be associated with challenges in preservation of the camel milk caused by the inability to process it into the shelf-stable products. The process of freeze-drying may be applied in order to retain the nutritional properties as well as technical and functional characteristics of the camel milk. Assessment of the effects of the isolation procedure and following freeze-drying on the mass yield of dry camel milk caseins and whey proteins could be interesting in order to get consolidated processes, which may further be transferred to an industrial level. These findings will play a central role in future freeze-drying operations since the retention of important nutritional components is an important part of food processing. In order to reveal the possible hurdles and to get a consolidated procedure to produce functional foods for different purposes, it is important to study the preceding data on isolation and preservation of camel milk proteins, as well as study their characteristics.
\end{abstract}

Key words: camel milk, caseins, freeze-drying, acid precipitation, SDS-PAGE, whey proteins.

\section{Introduction}

Kazakh population consumes large amounts of animal-originated food, with $237.7 \mathrm{~kg}$ of milk and dairy products (from cow, camel, mare) per person in 2018 [1]. In arid areas of South and West Kazakhstan, camel milk is an important part of nutrition of the local population [2], as habitants of these regions use camels as one of the basic sources of nutrients for many centuries. The number of camels in Kazakhstan is growing; reached approximately 230,000 heads to this moment [1].

Camel milk differs from cow milk in composition, protein content and structure [3]. The main groups of milk proteins are caseins and whey proteins. According to the literature data, caseins are the most common protein fraction, varying from 61.8 to $88.5 \%$ of the total milk protein. The components of camel milk $(\mathrm{CN})$ casein are homologous to cow milk casein: aS1-CN, aS2-CN, b-CN and k-CN. The proportion of each casein component as follows: aS1CN 22\%, aS2-CN 9.5\%, b-CN 65\% and k-CN 3.5\% $(\mathrm{w} / \mathrm{w})$. Casein fractions in camel milk are quite similar to bovine casein. At the same time the total amount of casein in camel milk can be lower (52-87\%) than in cow milk (80\%) [4]. Whey proteins of camel milk make up to $20-25 \%$ of all proteins and mainly consist of $\beta$-lactalbumin, lactoforin (also called GlyCAM-1), $\mathrm{IgG}$, lactoferrin and serum albumin. Accordingly, the ratio of whey protein fraction to casein fraction in camel milk is higher than in bovine milk, but lower than in breast milk [5]. Camel milk is characterized by the absence of $\beta$-lactoglobulin, one of the major allergens in bovine milk [6]. Finally, this milk contains high concentrations of various minerals, large amount of immune-active proteins, and is three times richer in vitamin $\mathrm{C}$ than bovine milk. All these components play an important role in the mechanisms of protection against diseases and are beneficial to the healing properties of camel milk [7].

The Food and Agriculture Organization (FAO) forecasts that global population will increase by third by 2050 [8]. The projections are such that with increase in population size, the demand for food products rich in protein will grow, and this in turn will stimulate high demand for milk protein. Consequently, the global dairy protein market should grow by an average of $7.8 \%$ over the next decade, reaching 
about $\$ 18.25$ billion by 2025 [9]. Since prevailing part of the population of West, East African and Central Asian countries have access to camel milk $(60 \%$ of the dromedary population is concentrated in the countries of North-East Africa) [7], demand for camel milk proteins will increase in these regions.

Camel milk, like any other milk, is highly perishable, with losses occurring during work at farm and under industrial conditions. These losses can be associated with challenges in preservation of the camel milk caused by inability to process it into the shelfstable dairy products. The process of freeze-drying minimizes reactions of decomposition and supports physical, chemical and biological stability of the product for a long time storage at ambient temperature [10].

Freeze-drying or lyophilization is a technological process used for soft drying of substances, during which dried product is frozen, and then placed in a vacuum chamber for sublimation of the solvent. Being a cold process, freeze-drying is especially useful for drying heat sensitive foods. Freeze-drying is recognized as the best method of water removal with final production of a highest quality dry materials compared to other methods of food drying. This process can be used in order to retain the nutritional properties and techno-functional characteristics of the milk [11]. Disadvantage of freeze-drying is its expensiveness and time consumption. Nevertheless, it is an important drying procedure for milk, which allows preserving its taste, good flavour appearance, and nutritive properties $[12 ; 13]$.

Assessment of the effects of the isolation procedure and following freeze-drying on the mass yield of dry camel milk caseins and whey proteins could be interesting in order to get consolidated processes, which may further be transferred to an industrial level. These findings will play central role in future freeze-drying operations since the retention of important nutritional components is an important part of food processing $[14 ; 15]$.

\section{Materials and methods}

Collection of milk samples. For the high representativeness of the method of random selection three multiparous 10-year-old camels were selected from a commercial farm in Almaty region. Camels were placed on pasture keeping with the provision of additional feeding in the cold period of the year. The main source of food for camels were natural plants growing in places of grazing. Camel milk was ob-

Int. j. biol. chem. (Online) tained by manual milking in accordance with generally accepted camel milking standards. During sampling period, on average from February to December, camels were milked thrice a day (at 6 a.m., 2 and 6 p.m.). Milk was collected jointly from the evening of the first day and from the morning of the next day. $2 \mathrm{~L}$ of milk were collected from each animal. For conservation, sodium azide, which does not affect the structure of milk proteins, was added at $0.02 \%$, immediately to the sampled milk before its transport to the laboratory in a cooler bag. All sampled milk has been transported in 5 hours after milking, kept at $4^{\circ} \mathrm{C}$ until they reached the laboratory, then frozen and stored at $4^{\circ} \mathrm{C}$ until the analysis.

Preparation of camel milk proteins. Camel milk was defatted by centrifugation at $5,000 \mathrm{~g}$ at $4^{\circ} \mathrm{C}$ for 30 min. After precipitation of skimmed milk by slowly adding $1 \mathrm{M} \mathrm{HCl}$ to $\mathrm{pH} 4.4$, the casein pellet was separated from the whey proteins by centrifuging at 5,000 $\mathrm{g}$ at $20^{\circ} \mathrm{C}$ for $30 \mathrm{~min}$. Then, both separated protein fractions were neutralized with $1 \mathrm{M} \mathrm{NaOH}$ and dialyzed against ultrapure water for 96 hours. Dialyzed proteins were freeze-dried (Martin Christ Alpha 1-4 LSC plus, Osterode am Harz, Germany) and stored at $4^{\circ} \mathrm{C}$ until the analysis.

Estimation of protein concentration. Thermo Scientific Pierce BCA Protein Assay Kit was used to check the protein concentrations. The Protein Assay was carried out with 1:2 and 1:10 times dilution of proteins in $\mathrm{dH}_{2} \mathrm{O}$ on the 96-well microplate by keeping the microplate in an incubator at $37^{\circ} \mathrm{C}$ for $30 \mathrm{~min}$. The absorption was read at $570 \mathrm{~nm}$ by BMG FLUOstar Galaxy - Multi-functional Microplate Reader (MTX Lab Systems, USA) for 96 -well $(217 \times 85 \mathrm{~mm})$ microplates.

Estimation of yield after freeze-drying. In the absence of data on protein fractions in the milk of the Kazakh breeds of dromedary (Camelus dromedari$u s)$, the obtained dry masses of each fraction were compared to reported concentrations of caseins and whey proteins in camel milk of dromedaries from Saudi Arabia, United Arab Emirates and Pakistan. In data, reported by Al-Alawi et al. [16], the mean value for protein content in the camel milk was $1.9 \%$ of caseins and $0.7 \%$ of whey proteins. However, this was slightly lower than the contents $(2.1$ and $0.8 \%$, respectively) reported by Rafiq et al. [17]. According to Khaskheli et al. [18], the casein content was slightly higher $(2.21 \mathrm{~g}$ per $100 \mathrm{~g})$. In this regard, for further calculations, the average concentrations of proteins obtained from these three studies was used as a theoretically expected protein mass, namely 20.6 $\mathrm{g}$ for casein and $7.5 \mathrm{~g}$ for whey protein per $100 \mathrm{~g}$ of camel milk. This ratio was expressed as follows: 
Yield $(\%)=($ obtained dry mass of a considered protein fraction / Theoretical expected concentration)*100

Characterization of camel milk proteins by SDS$P A G E$. The purity and electrophoretic profiles of all proteins were checked by Bio-Rad's SDS-PAGE System, following the method described by Laemmli, 1973 [17], with slight modification under reducing conditions on a $15 \%$ separation gel and $5 \%$ concentration gel. For preparing the separation gel for 2 mini-gels $3.75 \mathrm{~mL}$ of acrylamide/bis-acrylamide (1:29) solution was mixed with $2.5 \mathrm{~mL}$ of Tris buffer $\mathrm{pH} 8.8$ for separation gel with $2.5 \mathrm{~mL}$ of $\mathrm{dH}_{2} \mathrm{O}$ water, $100 \mu \mathrm{L}$ of $10 \%$ SDS, $5 \mu \mathrm{L}$ of tetramethylethylenediamine (TEMED) and $100 \mu \mathrm{L}$ of solution of $100 \mathrm{mg} /$ $\mathrm{mL}$ ammonium persulfate in a tube and thoroughly mixed. The solution was poured between the spacer and short plates and then gel was isolated from the air by using distilled water on the surface. When the gel solidified well, the distilled water was poured off. The top of the gel was dried using the filter paper. Then, $0.65 \mathrm{~mL}$ of acrylamide/bis-acrylamide (1:29) solution was mixed with $1.25 \mathrm{~mL}$ of Tris buffer $\mathrm{pH}$ 6.8 for separation gel with $3.15 \mathrm{~mL}$ of distilled water, $50 \mu \mathrm{L}$ of $10 \%$ SDS, $10 \mu \mathrm{L}$ of TEMED and $50 \mu \mathrm{L}$ of $100 \mathrm{mg} / \mathrm{mL}$ ammonium persulfate to compound the concentration gel. The mixture was then poured between the plates on the separation gel. When the concentration gel became solidified, it was washed with distilled water. The gel cassettes were loaded into electrophoresis tank, where $700 \mathrm{~mL}$ of electrode buffer $(70 \mathrm{~mL}$ of $10 \mathrm{x}$ electrode buffer mixed with $630 \mathrm{~mL}$ of $\mathrm{dH}_{2} \mathrm{O}$ ) was poured. For sample preparation, $100 \mu \mathrm{g}$ of each protein sample were incubated with the sample buffer at $1: 1$ ratio $(50 \%$ glycerol, $10 \%$ SDS, 2-mercaptoethanol, bromophenol blue) at $100^{\circ} \mathrm{C}$ for $5 \mathrm{~min}$ and then loaded into the gel. Run time was approx. $35 \mathrm{~min}$ at $200 \mathrm{~V}$. The gels were taken out carefully and put for 1 hour in $12 \%$ trichloroacetic acid for fixation. Then, the gels stained overnight with Sigma's Coomassie brilliant blue R250 $(0.1 \% \mathrm{w} / \mathrm{v})$. After discoloration, the gels were visualized, and images were captured under the visible light.

\section{Results and discussion}

The results of obtaining a mass of camel milk proteins from three camels were studied according to the methods described above. As can be seen from the obtained data, the $\mathrm{pH}$ of raw camel milk ranges from 6.4 to 6.5 and it is in line with the $\mathrm{pH}$ values reported by other studies on the camel milk [18-20].

Int. j. biol. chem. (Online)
The resulting weight of caseins fraction and the volume of whey proteins fraction were measured after the protein isolation before dialysis (Tables 1 and 2).

Table 1 - Results of casein separation

\begin{tabular}{|c|c|c|c|}
\hline & Camel 1 & Camel 2 & Camel 3 \\
\hline Quantity (L) & \multicolumn{3}{|c|}{2} \\
\hline pH of raw milk & $6.47-6.54$ & $6.45-6.50$ & $6.46-6.48$ \\
\hline $\begin{array}{c}\text { Weight (g) of wet } \\
\text { proteins after separa- } \\
\text { tion }\end{array}$ & -- & $403 \mathrm{~g}$ & $278 \mathrm{~g}$ \\
\hline
\end{tabular}

Table 2 - Results of whey separation

\begin{tabular}{|c|c|c|c|}
\hline & Camel 1 & Camel 2 & Camel 3 \\
\hline Quantity (L) & \multicolumn{3}{|c|}{2} \\
\hline pH of raw milk & $6.47-6.54$ & $6.45-6.50$ & $6.46-6.48$ \\
\hline $\begin{array}{c}\text { Volume (L) of } \\
\text { wet proteins after } \\
\text { separation }\end{array}$ & 1.6 & 1.4 & 1.4 \\
\hline
\end{tabular}

Due to the losses linked to a laboratory accident, the casein yield of Camel 1 has been excluded from the data analysis. In the case of whey proteins, the results obtained from the milk of three camels will be taken into account.

After obtaining separate protein fractions, to eliminate low molecular weight impurities and reduce the salt concentration, dialysis was carried out. The results obtained for dried caseins and whey proteins of camel milk are presented in Table 3.

Table 3 shows the mass of dried proteins obtained from 1L of the camel milk. From 1L of the camel milk $10.9 \mathrm{~g}$ of dry caseins and $3.1 \mathrm{~g}$ of dry whey proteins were obtained on average (Table 3 ). These quantifications would correspond to a yield between 32 and $66 \%$ of theoretically expected proteins in camel milk. From the literature data, it follows that from the mass of total protein ( $33.5 \mathrm{~g} / \mathrm{L}$ of camel milk) the proportion of caseins was $61.8-88.5 \%$, which is in terms of mass from $20.6 \mathrm{~g}$ to $29.6 \mathrm{~g}$, and the proportion of whey proteins in turn, ranged from 11.49 to $38.82 \%$, i.e. from $3.8 \mathrm{~g}$ to $13.0 \mathrm{~g}[5 ; 18]$. The mass of pure caseins obtained in this study (on average $10.9 \mathrm{~g}$ of dry caseins) was lower than the values from the literature data, while the obtained mass of whey proteins (on average $3.1 \mathrm{~g}$ of dry whey proteins) is comparable to the results shown by other researchers. 
Table 3 - Yield of camel milk proteins

\begin{tabular}{|l|c|c|c|c|c|}
\hline \multicolumn{1}{|c|}{ Protein fraction } & Camel 1 & \multicolumn{2}{c|}{ Camel 2 } & \multicolumn{2}{c|}{ Camel 3 } \\
\hline \multicolumn{1}{|c|}{ whey proteins } & caseins & whey proteins & \multicolumn{2}{c|}{ caseins } & whey proteins \\
\hline Mass of freeze-dried protein fraction (g) & 6.6 & 22.8 & 5.3 & 14.7 & 5.2 \\
\hline $\begin{array}{l}\text { Proportion of pure protein (\%) } \\
\text { (BCA-Pierce Dosage) }\end{array}$ & 56.5 & 60.2 & 59.9 & 55.5 & 45.6 \\
\hline Dry weight of purified protein (g) & 3.7 & 13.7 & 3.1 & 8.1 & 2.4 \\
\hline Yield $\left.^{\text {a }} \%\right)$ & 49.3 & 66.5 & 41.3 & 39.3 & 32.0 \\
\hline \multicolumn{2}{|c|}{ Note: ${ }^{a}$ Yield (\%) (Obtained dry mass / Theoretically expected dry mass)*100 } \\
\hline
\end{tabular}

Nevertheless, our reference values have been taken from the same camel breeds - Camelus dromedarius of Saudi Arabia and United Arab Emirates, reviewed by Al-Alawi et al. [16] and Pakistani breeds, reviewed by Khaskheli et al. [18], what allows us to suppose differences in protein contents in comparison to the camel milk of the local breeds. According to Konuspayeva et al. [23], the variability of camel milk composition is clearly dependent on geographical origin. In addition, such factors as dairy performance, feeding conditions or the physiological stage of the animals can increase variations in milk protein content. As the growing conditions may affect the rate of the protein synthesis in a notable manner, revealed differences to theoretical values have to be taken with cautions. To increase the statistical reliability, all experiments were performed in triplicate, after which the average values were taken.

Unfortunately, no specific Protein Assay Kit for camel milk proteins is available on the market. The colorimetric detection and quantitation of total proteins content, i.e. to determine the pure protein concentration in the obtained fractions colorimetric method performed with bovine serum albumin (SAB) is usually used as standard provided by the Pierce BCA Protein Assay Kit. The results of the colorimetric analysis (Figure 1) show that the obtained casein fractions contain from 48.5 to 60.2 (in average of $55 \%$ ) of pure proteins.

The question can be asked if this BCA-Pierce Assay kit would allow the quantification of fully camel caseins. Our results show clear variations in protein yields between different individuals as well as possibility of non-negligible losses. Nevertheless, yield of approximately $50 \%$ of initially contained proteins can be expected for both major protein fractions.

To determine the purity and homogeneity of each individual protein fraction (camel milk caseins and whey proteins) Bio-Rad's SDS-PAGE was carried out. In the lines CMWP-A, CMWP-S and CMWP-U

Int. j. biol. chem. (Online) (whey protein fractions), shown on the Figure 2, the protein bands can be observed with an apparent molecular weight (MW) of 14,000; 30,000 and 65,000 $\mathrm{Da}$, which are identified as $\alpha$-lactalbumin, IgGs 1 and serum albumin.

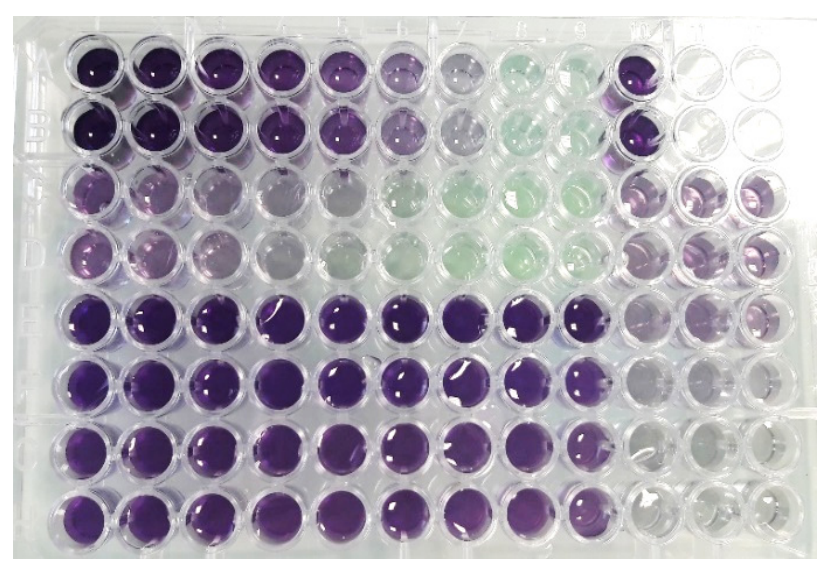

Figure 1 - The results of colorimetric analysis with caseins and whey proteins from all camel milk samples

These results are consistent with the data provided by Mati et al. [6], which showed that camel $\alpha$-lactalbumin has a molecular weight of $14.4 \mathrm{kDa}$, while the molecular weight of IgGs1 and serum albu$\min$ is 30 and $67 \mathrm{kDa}$, respectively.

In addition, in these lines protein bands were observed with an apparent Molecular Weight (MW) 12,000 and 19,000 Da, which were identified as whey acidic protein (WAP) and peptidoglycan recognition protein-1 (PGRP-1). These results were comparable with the literature data reported by Beg et al. [24] and Kappeler et al. [25], who found that the MW of WAP and PGRP-1 are 12,534 Da and 19,143 Da, respectively. In the lines CMC-A, CMC-S and CMC-U (casein fractions), protein bands were observed with an apparent MW of 21,000 and 24,000 Da, which 
are identified as $\beta-\mathrm{CN}$ and $\alpha-\mathrm{S} 2-\mathrm{CN}$ with $\mathrm{MW}$ of 24,650.76 Da and 21,265.90 Da, respectively, matching the data provided by Mati et al. [7]. After the performed electrophoresis, we were convinced that caseins and whey proteins from the camel milk were isolated correctly.

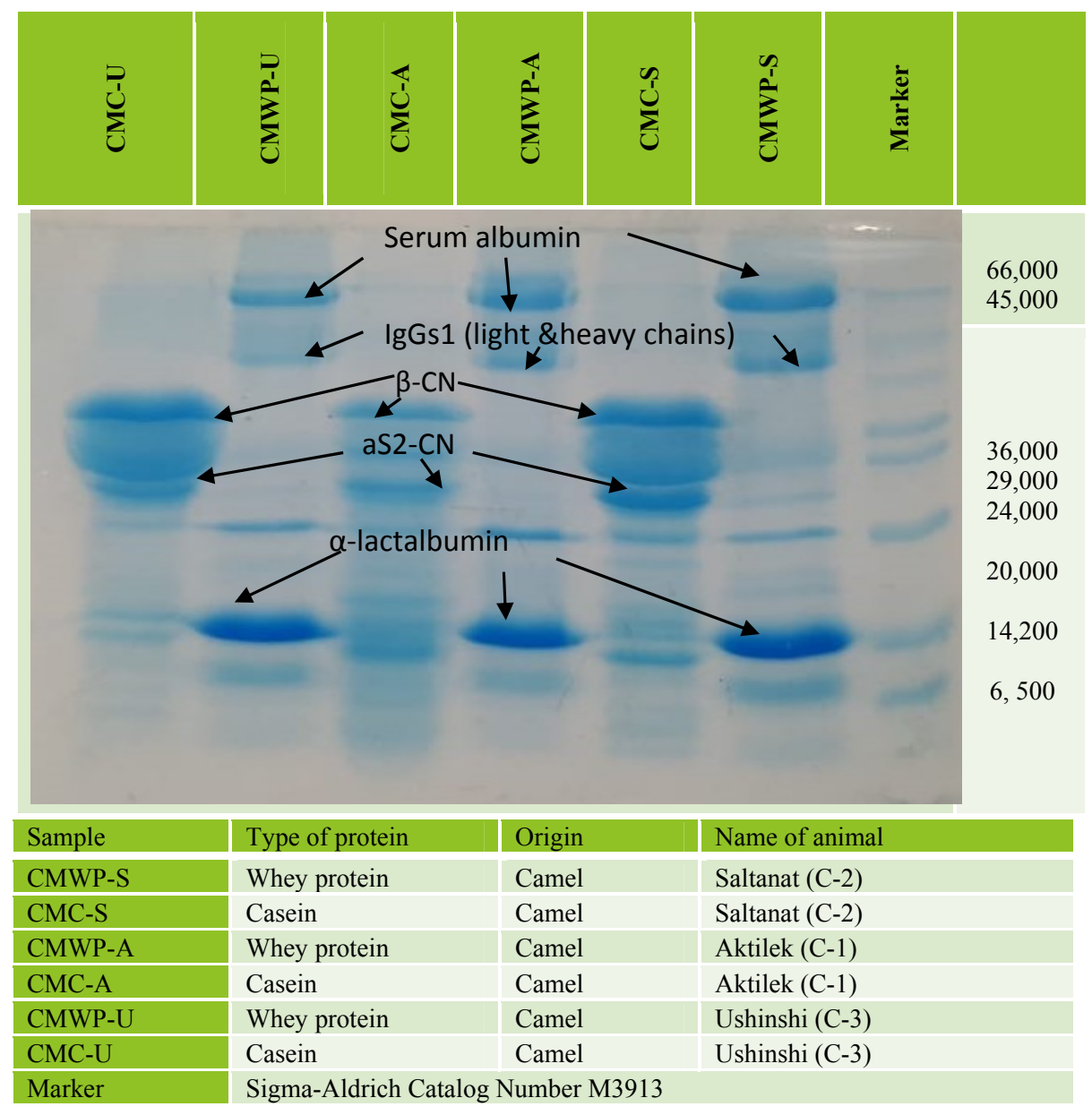

Figure 2 - Gel after SDS-PAGE with caseins and whey proteins from all camel milk samples

\section{Conclusion}

This work demonstrated that from $1 \mathrm{~L}$ of camel milk it is possible to get $8.1-13.7 \mathrm{~g}(10.9 \mathrm{~g} / \mathrm{L}$ in average) of pure caseins and 2.4-3.7 g (3.1 g/L in average) of pure whey proteins. The wide variability between the masses of the obtained protein fractions can be explained by the individual characteristics of each camel (geographical location, seasonality factor, physiological conditions, and health status). Separation of protein fractions by acid coagulation, classically used for cow milk, will work also in camel milk although an apparent yield of only around 50\% has been achieved. Improvements in quality are possible on the stages of re-solubilization of the fractions after separation as well as quality of dialysis, where the ratio between expected the protein mass and water volume should be especially re-considered. Moreover, a specific identification of caseins and whey proteins from Camelus dromedarius can improve the calculated yields.

Results of the present study are valuable for further evaluation of the properties of proteins and peptides of the camel milk, which have been studied for much less extent than such of the cow milk $[15 ; 17]$. Some studies were performed to study the properties of milk proteins of camels from the other countries [4-7]. However, since the geographic location plays an important role, the study of the properties of the camel milk proteins in Kazakhstani breeds is of par- 
ticular interest, since this issue has not been studied in our country yet. Therefore, new research in this direction is of interest to the international scientific community, which increases the significance of this work. The results of this current study will form the basis for further research on the peptides and milk proteins of camels habituating on the territory of Kazakhstan.

\section{References}

1. Committee on statistics of the Republic of Kazakhstan. Last modified April 28, 2019. http://stat. gov.kz

2. Petrlik J., Kalmykov D., Zatloukalova K. (2016) Toxic pollutants in camel milk from the Mangystau region of Kazakhstan, Results of sampling conducted in 2015-2016, $50 \mathrm{p}$.

3. Al-Shamsi K.A, Mudgil P., Hassan H.M., Maqsood S. (2018) Camel milk protein hydrolysates with improved technofunctional properties and enhanced antioxidant potential in in vitro and in food model systems. J Dairy Sci., vol. 101, no. 1, pp. 4760. https://doi.org/10.3168/jds.2017-13194

4. Khalesi M., Salami M., Moslehishad M., Winterburn J., Moosavi-Movahedi A.A. (2017) Biomolecular content of camel milk: a traditional superfood towards future healthcare industry. Trends Food Sci Tech., no. 62, pp. 49-58. https://doi.org/10.1016/j. tifs.2017.02.004

5. El-Agamy E.I. (2009). Bioactive components in camel milk, pp. 159-192. In: Bioactive components in milk and dairy products, ed. by Park Y.W., Wiley-Blackwell Publishers, Ames, Iowa and Oxford, England.

6. El-Agamy E.I., Nawar M.A. (2000) Nutritive and immunological values of camel milk: a comparative study with milk of other species. In: 2nd International Camelid Conference Agroeconomics of Camelid Farming, Almaty, Kazakhstan.

7. Mati A., Senoussi-Ghezali C., Zennia S.A., Almi-Sebbane D., El-Hatmi H., Girardet J-M. (2017) Dromedary camel milk proteins, a source of peptides having biological activities a review. Int Dairy $J$., no. 73, pp. 25-37. https://doi.org/10.1016/j.idairyj.2016.12.001

8. Food and Agriculture Organization of United Nations (2009). How to feed the world 2050, highlevel expert forum, Global agriculture towards 2050. FAO, Rome, 4 p.

9. Research and Markets. The world's largest market research store. Global Milk Protein Market Analysis \& Trends - Industry Forecast to 2025. Last

Int. j. biol. chem. (Online) modified April 19, 2019 https://www.researchandmarkets.com/reports/4115294/global-milk-proteinmarket-analysis-and-trends

10. Fonseca F., Passot S., Cunin O., Marin M. (2008) Collapse temperature of freeze-dried Lactobacillus bulgaricus suspensions and protective media. Biotechnol Prog., vol. 20, no. 1, pp. 229-238 https://doi.org/10.1021/bp034136n

11. Ibrahim A.H., Khalifa S.A. (2015) Effect of freeze-drying on camel's milk nutritional properties. Int Food Res J., vol. 22, no. 4, pp. 1438-1445.

12. Ratti C. (2001) Hot air and freeze-drying of high-value foods: a review. J Food Eng., no. 49, pp. 311-319. https://doi.org/10.1016/S02608774(00)00228-4

13. Yao Y., Zhao G., Yan Y., Chen C., Sun C., Zou X., Jin Q. and Wang X. (2016) Effects of freeze drying and spray drying on the microstructure and composition of milk fat globules. RSC Advances, vol. 6 , no. 4 , pp. $2520-2529$. https://doi.org/10.1039/ C5RA22323G

14. Munro P.A. (2002) Caseins, functional properties and food uses, pp. 1909-1915. In: Encyclopedia of Dairy Sciences, ed. by Fuquay J., Fox P.,. San Diego: Academic Press

15. Moughan P.J. (2009) Milk proteins: a cornucopia for developing functional foods, pp. 483499. In: Milk proteins from expression to food, ed. by Thompson A., Boland M. San Diego: Academic Press. https://doi.org/10.1016/B978-0-12-3740397.00017-9

16. Al-Alawi A.A., Laleye L.C. (2008) Characterization of camel milk protein isolates as nutraceutical and functional ingredients. Collaborative Research Project SQU/UAEU.

17. Rafiq S., Huma N., Pasha I., Sameen A., Mukhtar O., Khan M.I. (2016) Chemical composition, nitrogen fractions and amino acids profile of milk from different animal species. Asian-Australas J Anim Sci., vol. 29, no. 7, pp. 1022-1028. http:// dx.doi.org/10.5713/ajas.15.0452

18. Khaskheli M., Arain M.A., Chaudhry S., Soomro A.H., Qureshi T.A. (2005) Physico-chemical quality of camel milk. $J$ Agric Soc Sci., no. 2, pp. 164-166.

19. Laemmli U.K., Favre M. (1973) Maturation of the head of bacteriophage T4: I. DNA packaging events. J Mol Biol., vol. 80, no. 4, pp. 575-599. https://doi.org/10.1016/0022-2836(73)90198-8

20. Mal G., Dande S.S., Sahani M.S. (2006) Milk production potential and keeping quality of camel milk. J Camel Pract Res., vol. 13, no. 2, pp. 175-178. 
21. Mal G., Dande S.S., Sahani M.S. (2007) Changes in chemical and macro-minerals content of dromedary milk during lactation. J Camel Pract Res., vol. 14, no. 2, pp. 195-197.

22. Singh R., Mal G., Kumar D., Patil N.V., Pathak K. (2017) Camel milk: an important natural adjuvant. Agric Res., vol. 6, no. 4, pp. 327-340.

23. Konuspayeva G., Faye B., Loiseau G. (2009) The composition of camel milk: a meta-analysis of the literature data. J Food Compos Anal., vol. 22, no. 2, pp. 95-101. https://doi.org/10.1016/j. jfca.2008.09.008

24. Beg O.U., von Bahr-Lindström H., Zaidi Z.H., Jörnval H. (1984) A small camel-milk protein rich in cysteine/half-cystine. Bioscience Rep., vol. 4, no. 12, pp. 1065-1070. https://doi.org/10.1016/00145793(87)80704-4

25. Kappeler S.R., Heuberger C., Farah Z., Puhan Z. (2004) Expression of the peptidoglycan recognition protein, PGRP, in the lactating mammary gland. J Dairy Sci., vol. 87, no. 8, pp. 2660-2668.

26. Konuspayeva G., Faye B., Loiseau G., Levieux D. (2007) Lactoferrin and immunoglobulin contents in camel's milk (Camelus bactrianus, Camelus dromedarius, and hybrids) from Kazakhstan. J Dairy Sci., vol. 90, no. 1, pp. 38-46. https://doi. org/10.3168/jds.S0022-0302(07)72606-1 